\title{
PARTISIPASI MASYARAKAT DALAM PERENCANAAN PEMBANGUNAN DESA BANUT KALANAMAN KECAMATAN KATINGAN HILIR KABUPATEN KATINGAN
}

\author{
Community Participation in Development Planning of Banut Kalanaman Village, \\ Katingan Hilir Subdistrict, Katingan District
}

\section{Noor Hidayat* \\ Wahyu Hidayat}

Universitas Muhammadiyah

Palangkaraya, Palangka Raya,

Central Kalimantan, Indonesia

email:

noor.hidayat@umpalangkaraya.ac.id

\section{Kata Kunci:}

Partisipasi Masyarakat

Perencanaan Pembangunan

Desa

\section{Keywords:}

Society participation

Development Planning

Village

Accepted

July 2017

\section{Published}

October 2017

\begin{abstract}
Abstrak
Penelitian ini bertujuan menjelaskan, mendeskripsikan bagaimanakah Tingkat Partisipasi Masyarakat Dalam Perencanaan Pembangunan Desa Banut Kalanaman Kecamatan Katingan Hilir Kabupaten Katingan. Penelitian ini menggunakan metode penelitian kualitatif, sumber data terdiri dari sumber data primer (Kepala Desa, Ketua BPD, Pamong Desa, Ketua RT, dan Masyarakat), sumber data sekunder (Dokumen yang berkaitan dengan Partisipasi Masyarakat dalam Perencanaan Pembangunan Desa Banut Kalanaman). Teknik pengumpulan data dengan observasi, wawancara dan dokumentasi. Hasil penelitian menunjuk bahwa partisipasi masyarakat dalam perencanaan pembangunan cukup baik tetapi masih perlu ditingkatkan, karena (I) Kesadaran masyarakat untuk hadir dan ikut serta dalam perencanaan pembangunan desa masih lemah, (2) Keaktifan masyarakat dalam mengemukakan saran atau pendapatnya sangat rendah (3) Penyampaian informasi-informasi atau sosialisasi arah kebijakan pembangunan desa minim tidak sampai ke seluruh lapisan masyarakat desa, (4) Masyarakat tidak banyak terlibat dalam proses perencanaan, masyarakat seringkali menganggap rapat hanyalah formalitas belaka.
\end{abstract}

\section{PENDAHULUAN}

Era otonomi daerah dan desentralisasi, kepada daerah diberikan kewenangan yang nyata, luas dan bertanggung jawab. Pemberian kewenangan ini dimaksudkan agar daerah mampu merumuskan dan melaksanakan kebijakan serta langkah-langkah strategis dalam melaksanakan pembangunan daerah guna memajukan daerah dan meningkatkan kesejahteraan masyarakat. Otonomi dan desentralisasi dimaksudkan pula untuk menciptakan efisiensi dan efektifitas pengelolaan sumberdaya daerah, meningkatkan kualitas pelayanan umum, dan memberdayakan serta menciptakan ruang bagi masyarakat untuk ikut serta atau berpartisipasi dalam pelaksaan pembangunan daerah.

Untuk mewujudkan pembangunan desa yang terencana, maka pemerintah desa dan seluruh elemen masyarakat harus terlibat dalam proses perencanaan pembangunan. Desa Banut Kalanaman merupakan salah satu desa yang ada di Kecamatan Katingan Hilir Kabupaten Katingan Propinsi Kalimantan Tengah, desa ini belum maksimal 
melaksanakan perencanaan pembangunan yang partisipatif. Keikutsertaan masyarakat dalam penyusunan agenda pembangunan masih terlihat sesuatu yang asing bagi masyarakat, sehingga dalam perencanaan pembangunan masyarakat kecendrungan apatis atau enggan melibatkan diri, masyarakat lebih tertarik kepada masalah-masalah yang secara langsung terkait dengan kebutuhan sehari-hari seperti pemenuhan makan, tempat tinggal dan lain-lain.

Menurut pendapat Adi (2008) menjelaskan partisipasi masyarakat adalah keikutsertaan masyarakat dalam proses pengidentifikasian masalah dan potensi yang ada di masyarakat, pemilihan dan pengambilan keputusan tetang alternatif solusi untuk menangani masalah, pelaksanaan upaya mengatasi masalah, dan keterlibatan dalam proses mengevaluasi perubahan yang terjadi. Menurut Sumpeno (20II) perencanaan pembangunan desa merupakan suatu panduan atau model penggalian potensi dan gagasan pembangunan desa yang menitikberatkan pada peranserta masyarakat dalam keseluruhan proses pembangunan dalam konsep pembangunan partisipatif.

\section{METODOLOGI}

Penelitian ini akan mempergunakan metode deskriptif kualitatif karena data yang dikumpulkan lebih mengambil bentuk kata-kata atau gambaran dari pada angka- angka. Hasil penelitian tertulis berisi kutipan-kutipan dari data untuk mengilustrasikan dan menyediaan bukti presentasi.

Data tersebut mencakup transkip wawancara, catatan lapangan, fotografi, dokumen pribadi. Adapun tujuan akhir dari penelitian kualitatif, yaitu memahami apa yang di pelajari dari perspektif kejadian itu, oleh karena itu seorang peneliti dalam penelitian kualitatif hanya melaporkan pemahaman sebuah kejadian melalui kejadiannya sendiri.
Data deskriptif yang dikumpulkan dengan harapan dapat mengetahui bagaimana Partisipasi Masyarakat Dalam Perencanaan Pembangunan Desa Banut Kalanaman Kecamatan Katingan Hilir Kabupaten Katingan Provinsi Kalimantan Tengah.

\section{HASIL DAN PEMBAHASAN}

Tingkat Partisipasi Masyarakat Dalam Perencanaan Pembangunan Desa Banut Kalanaman secara umum cukup baik. Berikut uraiannya:

Keikutsertaan masyarakat dalam menghadiri rapat perencanaan pembangunan desa.

Menurut hasil penelitian yang dikumpulkan peneliti, tingkat kehadiran masyarakat mencerminkan partisipasi masyarakat yang belum optimal, hanya sebagian orang tertentu saja yang hadir. Masyarakat cenderung apatis atau enggan melibatkan diri, masyarakat lebih tertarik kepada masalah-masalah yang secara langsung terkait dengan kebutuhan sehari-hari seperti pemenuhan makan, tempat tinggal dan lain-lain padahal telah diundang, hal ini membuktikan kesadaran masyarakat untuk ikut serta dalam proses perencanaan pembangunan desa masih lemah dan ada yang memang tidak diundang dalam pelaksanaan rapat desa, mereka hanya diwakili saja oleh para elit desa.

Mengemukakan pendapat atau saran dalam setiap pertemuan/rapat

Salah satu wujud partisipasi masyarakat dalam perencanaan pembangunan adalah melalui partisipasi aktif. Keterlibatan masyarakat itu, yaitu masyarakat mau menyampaikan pendapat atau saran, ide, ataupun gagasan. Berdasarkan hasil penelitian di lapangan, masyarakat desa Banut Kalanaman hanya menyumbang tenaga kerja saja berupa gotong royong, tidak ada sumbangan pendapat atau saran dalam rapat penyusunan rencana pembangunan. Apabila dilihat dari segi keaktifannya dalam mengemukakan pendapat atau saran, berdasarkan data yang diperoleh Peneliti tingkat 
keaktifan peserta sangat rendah. Hal ini disebabkan karena kurangnya pemahaman dari peserta mengenai perencanaan desa itu sendiri dan juga karena kurangnya pengetahuan serta keterampilan dari peserta.

Hal ini disebabkan karena latar belakang pendidikan masyarakat di Desa Banut Kalanaman dilihat dari monografi desa mayoritas hanyalah tamatan SD. Tidak ada inisiatif atau kreatifitas masyarakat untuk menyampaikan saran atau pendapat saat rapat perencanaan desa, padahal saran pendapat bahkan kritik sangat penting mengingat tujuan pembangunan desa itu untuk kesejahteraan mereka sendiri, hal ini membuktikan SDM masyarakat belum memadai sehingga partisipasi masyarakat terutama dalam proses perencanaan tidak maksimal.

Memberikan datalinformasi dalam setiap pertemuan/rapat pembangunan

Kondisi di Desa Banut Kalanaman, Informasi tentang program- program yang akan dilaksanakan selalu diinformasikan tetapi hanya untuk orang-orang tertentu saja seperti Ketua RT, staf desa, BPD dan sebagian masyarakat saja. Informasi-informasi atau sosialisasi arah kebijakan pembangunan yang minim tidak sampai ke seluruh lapisan masyarakat desa. Walaupun ada, masyarakat hanya mendengarkan pada saat musrenbang saja dan kurangnya pemahaman masyarakat terhadap informasi tersebut akhirnya masyarakat tidak mampu berinovasi atau berinisiatif untuk menyuarakan aspirasinya atau mengkritisinya yang pada akhirnya partisipasi masyarakat untuk memberikan data/informasi yang diperlukan untuk perencanaan pembangunan desa sangat kurang.

Keikutsertaan masyarakat dalam proses/perumusan pembuatan keputusan

Berdasarkan hasil penelitian di lapangan masih ada beberapa RT yang tidak melaksanakan Musyawarah RT dan masyarakat tidak ikut dalam merumuskan keputusan perencanaan pembangunan. Walaupun ada hanya segelintir elit saja yang ikut serta dalam perumusan tersebut.

Masyarakat tidakdiberdayakan dalam proses perumusan pembuatan keputusan, sehingga masyarakat seringkali menganggap rapat hanyalah formalitas belaka. Hal ini diperparah oleh sikap masyarakat sendiri yang apatis dalam kegiatan-kegiatan pembangunan. Oleh karena itu masyarakat tidak dapat berbuat banyak pada saat proses/perumusan pembuatan keputusan, karena masyarakat tidak banyak terlibat dalam proses perencanaan sebelumnya. Peran serta masyarakat dalam perencanaan program pembangunan desa akhirnya terbatasi.

Berdasarkan interprestasi penulis ada beberapa faktor yang menghambat partisipasi masyarakat Desa Banut Kalanaman sehingga kurang maksimal antara lain sebagai berikut:

Pendidikan/Sumber Daya Manusia (SDM)

Pengetahuan dan wawasan masyarakat desa Banut Kalanaman masih terbatas merupakan hambatan dalam meningkatkan partisipasi masyarakat dalam pembangunan desa Banut Kalanaman terutama dalam penyampaian ide atau pikiran dalam proses pembangunan. Tingkat pendidikan berdasarkan data profil desa Banut Kalanaman, bahwa penduduk desa buta huruf, tidak tamat SD, dan tamat SD berjumlah 931 orang atau $67 \%$ dari penduduk desa. Rendahnya tingkat pendidikan dan pengetahuan masyarakat yang menyebabkan kurangnya kemampuan masyarakat berpartisipasi dalam menerima dan menyerap informasiinformasi pembangunan, demikian pula dalam perencanaan.

Sosialisasi

Masalah lainnya adalah sosialisasi perencanaan yang belum maksimal. Menurut pamong desa sosialisasi itu sudah disampaikan dalam forum Musrenbang. Tetapi menurut penduduk/tokoh masyarakat hal itu hanya pada saat musrenbang, tidak semua masyarakat hadir dalam 
musrenbang, artinya tidak semua masyarakat mendengarkan sosialisasi tersebut. Kegiatan sosialisasi itu perlu dilakukan. Kegiatan sosialisasi itu bertujuan untuk menginformasikan proses perencanaan, sehingga masyarakat atau pelaku yang terlibat memiliki pemahaman, penerimaan dan kesadaran untuk berpartisipasi dalam proses perencanaan pembangunan desa.

Keterwakilan masyarakat tidak terpenuhi

Dalam peraturan Mendagri Nomor II4 Tahun 2014 pasal 25 ayat 3 unsur masyarakat yang seharusnya hadir adalah tokoh adat, tokoh agama, tokoh masyarakat, tokoh pendidikan, perwakilan kelompok tani, kelompok nelayan dan seterusnya. Dalam rapat musrenbang tersebut yang hadir hanya orang-orang tertentu saja, seperti kepala desa, staf desa, BPD, ketua RT, dan beberapa orang anggota masyarakat yang berjumlah tiga puluh dua orang saja. Walaupun kehadiran masyarakat itu ada keterwakilan, tetapi dalam hal ini dari daftar hadir kehadiran itu tidak mencerminkan keterwakilan masyarakat yang utuh. Yang hadir kebanyakan adalah ibu-ibu, tokoh-tokoh tersebut tidak ada.

\section{KESIMPULAN}

Berdasarkan hasil penelitian, Partisipasi masyarakat Dalam Perencanaan Pembangunan Desa Banut Kalanaman Kecamatan Katingan Hilir Kabupaten Katingan cukup baik tetapi masih perlu ditingkatkan, karena kesadaran masyarakat untuk ikut serta dalam perencanaan pembangunan desa masih lemah. Apabila dilihat dari segi tingkat keaktifan masyarakat dalam mengemukakan saran atau pendapatnya sangat rendah. Penyampaian informasi-informasi atau sosialisasi arah kebijakan pembangunan desa minim tidak sampai ke seluruh lapisan masyarakat desa. Masyarakat tidak ikut dalam merumuskan keputusan perencanaan pembangunan. Masyarakat seringkali menganggap rapat hanyalah formalitas belaka. Adapun faktor-faktor Penghambat Partisipasi Masyarakat Dalam Perencanaan
Pembangunan Desa Banut Kalanaman Kecamatan Katingan Hilir Kabupaten Katingan, yaitu pendidikan/Sumber Daya Manusia (SDM) Terbatas, Sosialisasi yang belum maksimal, dan Keterwakilan masyarakat tidak terpenuhi.

\section{REFERENSI}

Adi, Isbandi Rukminto. 2008. Intervensi Komunitas, Jakarta : Rajawali Pers.

Britha, Mikkelsen. 20II. Metode Penelitian Partisipatoris dan Upaya Pemberdayaan: Panduan Bagi Praktisi Lapangan, Jakarta : Yayasan Pustaka Obor Indonesia.

Emzir. 2010. Metodologi Penelitian Kualitatif Analisis Data, Jakarta : PT. Raja Grafindo Persada.

Gaffar Karim, Abdul. 2003. Kompleksitas Persoalan Otonomi Daerah Di Indonesia,Yogyakarta : Pustaka Pelajar.

Handayani, I.T. 2016. Partisipasi Perempuan Pada Pemilu Legislatif Tahun 2014 di Kota Palangka Raya. Restorica: Jurnal Ilmiah IImu Administrasi Negara dan Ilmu Komunikasi. 2(I):25-30.

Jayadinata, J.T dan Pramandika, I.G.P. 2006. Pembangunan Desa Dalam Perencanaan, Bandung : ITB.

Munir, Badrul. 2002. Perencanaan Pembangunan Daerah Dalam Perspektif Otonomi Daerah. Mataram : BAPPEDA NTB.

Nasution, Zulkarnain. 2009. Solidaritas Sosial Dan Partisipasi Masyarakat Desa Transisi, Malang : UMM Press.

Nurcholis, Hanif. 20Il.Pertumbuhan dan Penyelenggaraan Pemerintahan Desa. Jakarta : Erlangga.

Peraturan Pemerintah Republik Indonesia Nomor 43 Tahun 2014 Tentang Peraturan Pelaksanaan Undang-Undang Nomor 6 Tahun 2014 Tentang Desa.

Peraturan Menteri Desa, Pembangunan Daerah Tertinggal, Dan Transmigrasi Republik Indonesia Nomor 2 Tahun 2015 Tentang Pedoman Tata Tertib Dan Mekanisme Pengambilan Keputusan Musyawarah Desa. 
Peraturan Menteri Dalam Negeri Republik Indonesia Nomor 66 Tahun 2007 Tentang Perencanaan Pembangunan Desa.

Peraturan Menteri Dalam Negeri Republik Indonesia Nomor II4 Tahun 2014 Tentang Pedoman Pembangunan Desa.

Peraturan Desa Nomor 0I Tahun 2016 Tentang Rencana Pembangunan Jangka Menengah Desa (RJMDes).

Sjafrizal. 2014. Perencanaan Pembangunan Daerah Dalam Era Otonomi, Jakarta : PT. Raja Grafindo Persada.

Soetomo. 2013. Strategi - Strategi Pembangunan Masyarakat, Yogyakarta : Pustaka Pelajar.

Sumpeno, Wahjudin. 20I I. Perencanaan Desa Terpadu. Sukabumi : Read Indonesia.

Sugiyono. 2006. Metode Penelitian Kuantitatif Kualitatif Dan R \& D. Bandung : CV.Alfabeta.

Widjaja, HAW. 20I0. Otonomi Desa Merupakan Otonomi Yang Asli, Bulat Dan Utuh, Jakarta : PT. Raja Grafindo Persada.

Undang-Undang Republik Indonesia Nomor 6 Tahun 2014 Tentang Desa. 